\title{
The role of calcium in development of leg deformities in emu birds (Dromaius novaehollandiae)
}

Keywords: calcium, Emu, leg deformities

\section{Short Communication}

This report investigated the role of low levels of serum calcium in development of leg deformities in emu birds. Serum was collected from the emu birds which were showing both leg deformities and estimated the calcium levels which revealed a significant reduction in calcium levels than do the apparently healthy birds. Birds were administered with oral calcium supplementation, but the morphology of leg deformities was not changed up to two months of observatory period except in two birds out of ten affected birds. The study suggests concluding that calcium alone is not responsible for development of leg deformities, but it is a multi-factorial problem in emu birds. Therefore, provision of balanced diet can play an important role in the prevention of leg deformities in emu birds.

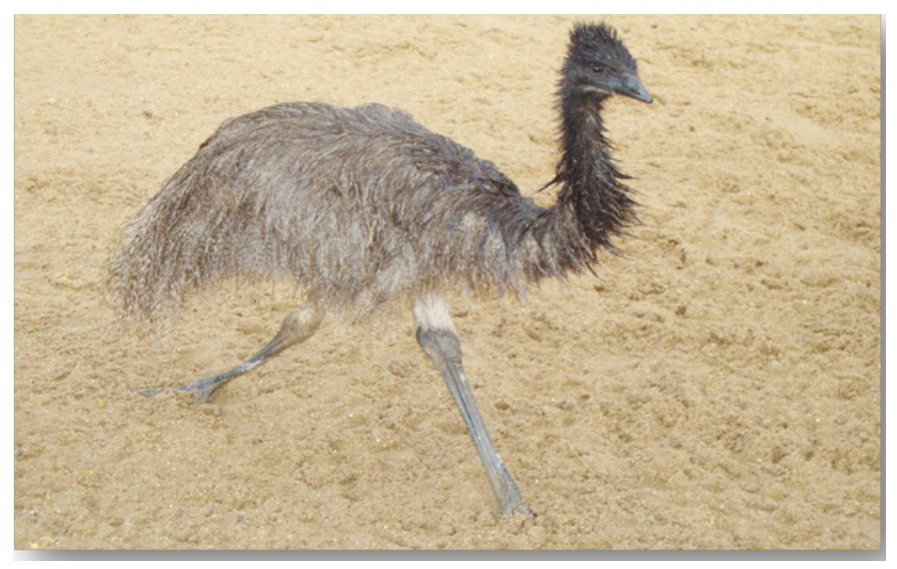

Figure I Leg deformities in emu bird (Dromaius novaehollandiae) observed in the present study.

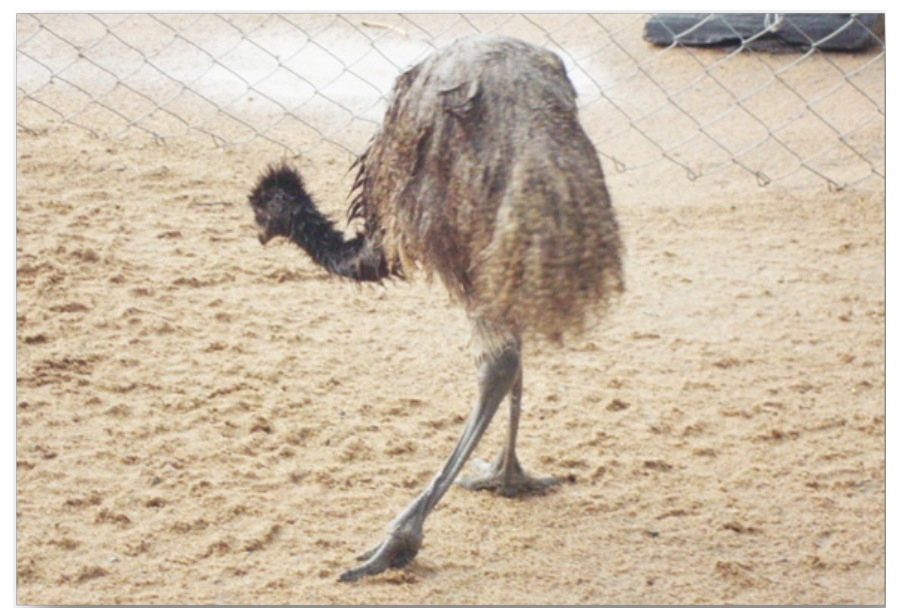

Figure 2 Leg deformities in another emu bird used for the present observation.

Emu farming in India is gaining commercial importance. Report on leg deformities due to hypocalcaemia was scanty for emu birds. Hence, this communication reports investigated effect of calcium
Volume 4 Issue 5 - 2019

\author{
Sudhakara Reddy B \\ Faculty of Veterinary Medicine, Sri Venkateswara Veterinary \\ University, India
}

Correspondence: Sudhakara Reddy B, College of Veterinary Science, Sri Venkateswara Veterinary University, Andhra Pradesh, India, Email bhavanamvet@gmail.com

Received: February 27, 2018 | Published: April 22, 2019

levels on emu birds specifically as a cause for leg deformities (Figure 1 \&2). Birds were administered with oral calcium preparations (Syrup containing vitamin A, Calcium and Vitamin D3 and vitamin B12) daily twice in drinking water for the period of three months.

Leg deformities were noticed in emu bird's age between 4 to 5 months old. Blood was collected from the jugular vein of emu birds showing both leg deformities $(\mathrm{n}=10)$ and apparently healthy birds in another farm $(n=6)$ to estimate the serum calcium levels. The study revealed that birds affected with leg deformities showed a significant reduction in their calcium levels $(9.89 \pm 0.73 \mathrm{mg} / \mathrm{dL})$ than do healthy birds $(12.15 \pm 1.68 \mathrm{mg} / \mathrm{dL})$. However, clinical examination of the birds after two months of the therapy did not reveal any significant change in leg deformities except in two birds out of ten affected birds. Recorded levels of calcium in apparently healthy birds in the present study were in line with the findings of previous studies. ${ }^{1}$ In the present study, there was a significant decrease in serum calcium levels in emus affected with leg deformities than healthy emus, which was also in agreement with previous studies. ${ }^{2}$ Similarly, Aganga et al. also reported limb deformities and affected bone structures in birds with low calcium levels. ${ }^{3}$

The study suggests concluding that calcium alone is not responsible for the development of leg deformities, but it is caused by multifactorial problem in emu birds. ${ }^{4}$ However, other elements, including manganese, zinc, and selenium, copper and iron were not estimated in the present study due to lack of instrumentation at the local area. Hence, provision of balanced diet can play an important role in the prevention of leg deformities in emu birds.

\section{Acknowledgments}

None.

\section{Conflicts of interest}

Author declares that there is no conflict of interest.

\section{References}

1. Reddy LSSVP, Naik BR, Reddy BS, et al. Changes in hematological and serum biochemical values of emus (Dromaius novaehollandiae) affected with leg deformities. Int J Curr Microbiol App Sci. 2018;7(9):723-728. 
2. Kozel CA, Kinney ME, Hanley CS, et al. Medical management of hypovitaminosis $\mathrm{d}$ with cholecalciferol and elastic therapeutic taping in red-legged seriema (Cariama cristata) Chicks. Journal of Avian Medicine and Surgery. 2016;30(1):53-59.

3. Aganga AA, Aganga AO, Omphile UJ. Ostrich Feeding and Nutrition. Pakistan Journal of Nutrition. 2003;2:60-67.
4. Kirkwood J. Twisting and bending deformities of the long bones in growing birds. In: Samour, editor. UK Mosby: Avian Medicine London; 2000. p. 173-176. 